\title{
Commodity Price Stabilization under Unattainable Stocks
}

\author{
Andrew Schmitz \\ Department of Food and Resource Economics, University of Florida, Gainesville, USA \\ Email: aschmitz@ufl.edu
}

How to cite this paper: Schmitz, A. (2018) Commodity Price Stabilization under Unattainable Stocks. Theoretical Economics Letters, 8, 861-865.

https://doi.org/10.4236/tel.2018.85061

Received: February 9, 2018

Accepted: April 5, 2018

Published: April 8, 2018

Copyright (C) 2018 by author and Scientific Research Publishing Inc. This work is licensed under the Creative Commons Attribution International License (CC BY 4.0).

http://creativecommons.org/licenses/by/4.0/

\begin{abstract}
Commodity price stabilization continues to be a subject of keen interest to policy makers. The general conclusion within the context of welfare economics is that price stabilization brought about through stockholding activities leads to a net welfare improvement to society even though there are gainers and losers from price stabilization policies. Under the standard price expectation formulation used, storage does not result in complete price stability, but in price fluctuations within a positive price band. However, it does generate price stability under an alternative price expectation framework. Under the standard price expectation formulation, the gains from stability are positive, but much less than under an alternative price expectation specification.
\end{abstract}

\section{Keywords}

Commodity Storage, Price Stabilization, Price Uncertainty

\section{Introduction}

Price stability is a condition in which prices change very little as a result of economic forces, including policies such as storage. In the absence of policy, prices can become very volatile. Commodity price stabilization continues to be a subject of keen interest to policy makers where the role of stockholding is the key to the discussion in providing stability. Part of the interest is the current major focus on the role of stocks especially in Feed the Future African countries. Schmitz and Kennedy [1] and Kennedy, Schmitz, and van Kooten [2] provide an overview of case studies on the impact of commodity storage, including the effect on price instability and food security. Generally, stocks are discussed within the context of the earlier welfare economic framework discussed below.

The early literature focused on the use of storage as a means to bring about 
price and income stability [3]-[13]. The general conclusion within the context of welfare economics is that price stabilization brought about through stockholding activities leads to a net welfare improvement to society even though there are gainers and losers from price stabilization policies. However, we demonstrate that the long held conclusion that there is a net welfare improvement from price stability holds under a different producer price expectation. The producer price expectation used in the standard literature only generates a storage amount that leads to a reduction in price instability, rather than eliminating it. Therefore, the gains from stabilization through storage can be much smaller than in the standard formulation. Under a price expectation framework where stocks are attainable, storage does not result in complete price stability. Rather, storage increases price stability, but the final result is that a price band is created. Also, the strong assumption that government does the storage is not needed as producers can bring about an equivalent result.

\section{The Theoretical Basis}

The theory upon which this paper is based is classical welfare economics that utilizes the concepts of consumer and producer surplus. The theoretical foundation for classical welfare economics can be found in Just, Hueth, and Schmitz [13].

\section{Storage and Supply Shocks}

The general approach in the standard literature is discussed with reference to Figure 1. Price $(P)$ is measured on the y-axis and Quantity $(Q)$ on the $\mathrm{x}$-axis. Consumer demand is $D_{s}$ and the stochastic supply is $S_{1}$ and $S_{2}$, each of which occurs with equal probability of one-half. Thus, equilibrium prices are $p_{1}$ and $p_{2}$ respectively. As we now discuss, under an expected price of $p_{2}$ and an expected quantity of $q_{2}$, coupled with an expected price of $p_{1}$ and expected quantity of $q_{1}$, the result cited in the literature on the effect of storage cannot hold. This is because the mean quantities produced are not those demonstrated in the standard

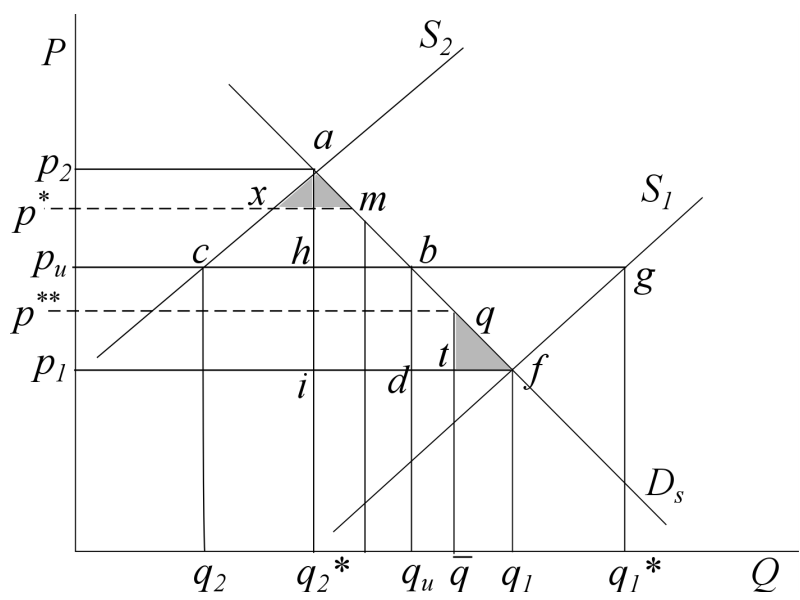

Figure 1. Storage and Supply Shocks: Price v. Quantity. 
framework. As a result, storage decreases price stability rather than generating complete price stability.

Massell [5] assumes that prices are stabilized at $p_{u}$ through a buffer-stock government authority that buys excess supply $\left(q_{1}^{*} q_{u}\right)$ at $S_{1}$ and sells $\left(q_{2} q_{u}\right)$ at $S_{2}$. Several well-known results fall out of this model on the comparison between price stability (through buffer stocks) and price instability. There is a net gain from stability [5] but there are also losers [3] [4].

In the literature, storage brings about a stable price of $p_{u}$ (Figure 1). In period 1 , the government stores $(b g)$ and releases stocks $(c b)$ in period $2\{(b g)=(c b)\}$. The net gain from price stabilization is $(a b c)+(b f g)$. The area $(a b c)$ is equal to $\left\{\left(p_{1} p_{u} b a\right)-\left(p_{1} p_{u} c a\right)\right\}$ while $(b f g)$ is equal to $\left\{\left(p_{u} p_{2} f g\right)-\left(p_{u} p_{2} f b\right)\right\}$. Based on these results, consumers prefer instability and producers prefer stability. But, on net, society benefits from stability. This is correct provided that the mean production that brings about the stable price $p_{u}$ is $q_{u}$.

Given that in period 1 producers expect price $p_{1}$ and quantity $q_{1}$, and in period 2 they expect price $p_{2}$ and quantity $q_{2}$, the amount of attainable storage in equilibrium cannot be $q_{2} q_{u}$. This is because the mean quantity over the two periods is $\bar{q}$ rather than $q_{u}$. Therefore, the amount of storage in equilibrium is $\bar{q} q_{1}=x m$ (the amount of stocks released in period 2). This amount of storage gives rise to a price band of $p^{* *} p^{*}$. Therefore, when storage is evaluated under the price expectations formulated in this model, storage cannot bring about complete price stability. As a result, the price gain from stabilization in period 1 is no longer $(b f g)$, but rather $(q t f)$, which is significantly smaller than $(b f g)$. Correspondingly, in period 2, the gains from stabilization are (axm), which is significantly smaller than $(a c b)$. Therefore, in this framework, the gains from stabilization can be much smaller than in the original models developed. However, there are still gains from stabilization since the net gain from stabilization is $\{(a x m)+(q t f)\}$, even though consumers prefer price instability (the Waugh result [3]), while producers prefer stability.

The key to the conclusion that storage reduces price instability but doesn't bring about complete stability is that producer price expectations are not conditioned on storage. Price expectations are formed and production takes place in period 1. After the harvest, the government then stores the commodity when quantities are already known. This has to be the case given the price expectation framework used in the standard models. However, the standard and cited results in the literature can be salvaged under a different price expectation framework. The producers' price expectation must be $p_{u}$ for each period, where they expect a quantity to be produced in period 1 of $q_{1}^{*}$ and $q_{2}$ in period 2 . This has to include an expectation on the part of producers that the government will store a quantity of $\left(q_{u} q_{1}^{*}\right)$ if produced. Thus, the expected prices in this model have to simultaneously combine production and storage.

Much of the literature assumes that stocks are held by the government, but this need not be the case. In the above model, it is to the benefit of producers to hold stocks, and there is no need for government storage. 


\section{Storage and Demand Shocks}

To add further evidence as to why storage lessens price instability, but doesn't completely eliminate it, consider Figure 2 where price instability is generated by $D_{1}$ and $D_{0}$. Price $(P)$ is measured on the y-axis and Quantity $(Q)$ on the x-axis. In period 1, producers expect price $p_{1}$ and production $q_{1}$. In period 2, they expect price $p_{2}$ and production $q_{2}$. This is the expectation framework presented in the well-known paper by Oi [4]. If the price could be stabilized at $p_{u}$, the net gain from stabilization is $\{(a b e)+(d c b)\}$. However, even though the net gains are positive, producers lose from stability.

However, given the above price and quantity expectations specified, it is impossible to stabilize at $p_{u}$, since the storage amount needed, which is (be), is not attainable from production. This can easily be seen since the mean production for $p_{u}$ to occur is $q_{u}$, whereas the correct mean production for $q_{1}$ and $q_{2}$ is $q^{*}$. As a result, with storage, the price in period 1 is $p^{*}$, while the price in period 2 is $p^{* *}$. Now the gains from stabilization are $\{(a f g)+(m n c)\}$, which is much smaller than described earlier.

\section{Conclusions}

As we have shown, storage reduces price instability, but cannot eliminate it within the price expectations underlying the standard storage models. This is the case regardless of whether instability comes about by production or demand shocks. This is also important from a policy perspective since one should not assume that storage policy is a failure if it cannot achieve complete price stability.

There are two major limitations to the framework and price expectation modeling that is done above. A modified price expectation model should be developed where storage is not needed to bring about complete price stability. Second, uncertainty is missing from our model. Under uncertainty, the price and quantity expectations are not realized. This can further complicate the gains and

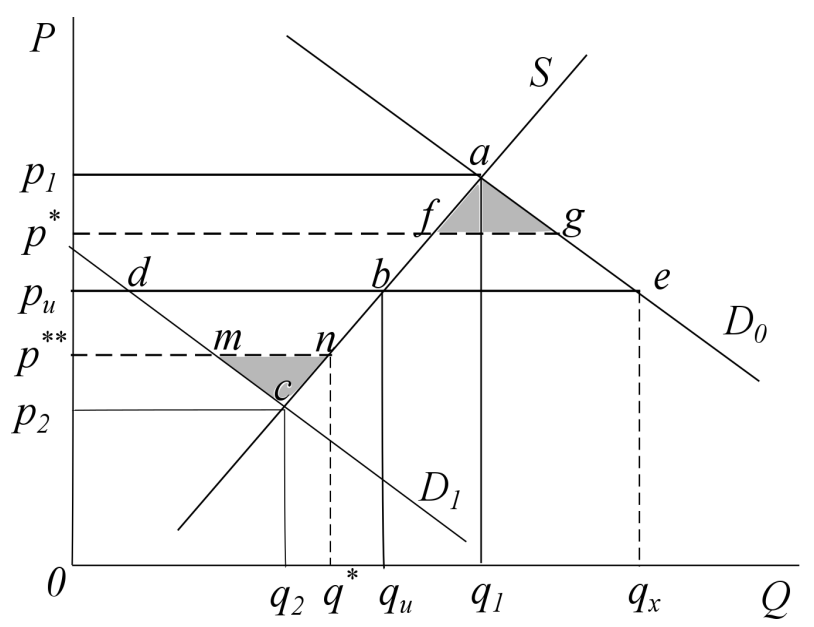

Figure 2. Storage and Demand Shocks: Price v. Quantity. 
losses from storage policy. Further price expectation models should be developed where storage is part of the price expectation framework.

\section{Acknowledgements}

The author thanks Claudine Chegini for technical assistance and editorial contributions.

\section{References}

[1] Schmitz, A. and Kennedy, P.L. (2016) Food Security and the Role of Food Storage. In: Schmitz, A., Kennedy, P.L. and Schmitz, T.G., Eds., Food Security in a Food Abundant World: An Individual Country Perspective, Emerald Group Publishing, Bingley, 1-18. https://doi.org/10.1108/S1574-871520150000016001

[2] Kennedy, P.L., Schmitz, A. and van Kooten, G. (2018) Food Security and Food Storage.

[3] Waugh, F.V. (1944) Does Instability Benefit from Price Instability? Quarterly Journal of Economics, 58, 602-614. https://doi.org/10.2307/1884746

[4] Oi, W.Y. (1961) The Desirability of Price Instability under Perfect Competition. Econometrica, 29, 58-64. https://doi.org/10.2307/1907687

[5] Massell, B.F. (1970) Some Welfare Implications of International Price Stabilization. Journal of Political Economy, 78, 404-417. https://doi.org/10.1086/259637

[6] Samuelson, P.A. (1972) The Consumer Does Benefit from Feasible Price Stability. Quarterly Journal of Economics, 86, 476-493. https://doi.org/10.2307/1880805

[7] Hueth, D.L. and Schmitz, A. (1972) Trade in Intermediate and Final Goods. Quarterly Journal of Economics, 86, 351-365. https://doi.org/10.2307/1880797

[8] Bieri, J. and Schmitz, A. (1973) Export Instability, Monopoly Power, and Welfare. Journal of International Economics, 3, 389-396. https://doi.org/10.1016/0022-1996(73)90030-5

[9] Bieri, J. and Schmitz, A. (1974) Market Intermediaries and Price Instability: Some Welfare Implications. American Journal of Agricultural Economics, 56, 280-285. https://doi.org/10.2307/1238756

[10] Newbery, D.M.G. and Stiglitz, J.E. (1981) The Theory of Commodity Price Stabilization. Clarendon Press, Oxford.

[11] van Kooten, G. and Schmitz, A. (1985) Commodity Price Stabilization: The Price Uncertainty Case. Canadian Journal of Agricultural Economics, 18, 426-434. https://doi.org/10.2307/135146

[12] van Kooten, G., Schmitz, A. and Furtan, H. (1988) The Economics of Storing a Non-Storable Commodity. Canadian Journal of Economics, 21, 579-586. https://doi.org/10.2307/135439

[13] Just, R.E., Hueth, D.L. and Schmitz, A. (2004) Welfare Economics and Public Policy. Prentice-Hall Press, Englewood Cliffs. 